\title{
Ipratropium Bromide
}

National Cancer Institute

\section{Source}

National Cancer Institute. Ipratropium Bromide. NCI Thesaurus. Code C29128.

The bromide salt form of ipratropium, a synthetic derivative of the alkaloid atropine with anticholinergic properties. Ipratropium antagonizes the actions of acetylcholine at parasympathetic, postganglionic, effector-cell junctions. When inhaled, ipratropium binds competitively to cholinergic receptors in the bronchial smooth muscle thereby blocking the bronchoconstrictor actions of the acetylcholine mediated vagal impulses. Inhibition of the vagal tone leads to dilation of the large central airways resulting in bronchodilation. 